\title{
ダンスロボットの開発とその主観的評価
}

\author{
松 浦 壮 一* 藤 城 智 子* \\ 山本一道** 井口信 洋*
}

\section{Development of Dancing Robot and its Subjective Judgement}

\author{
Soichi MATSUURA \\ Tomoko FUJISHIRO \\ Kazumichi YAMAMOTO \\ Nobuhiro IGUCHI
}

\begin{abstract}
Dancing robots are a kind of performance robots. It is not only to be able to dance but also to be able to make spectartors feel familiar and mild. For this purpose, this dancing robot was manufactured after consideration factors of subjective judgement. Image design technique was adopted for familiar shape and SMA actuator was adopted for smooth action of arms and legs. It was investigated that spectators' image for this dancing robot with Semantic Defferential Technique what was one of subjective judgement technique in psychology. This dancing robot's achivement was finally evaluated with a respect to its familality. As a conclusion of this development, it was indecated that Semantic Defferential Technique gave basis of psycological engineering design of performance robots.
\end{abstract}

Key Words : Performance Robot, Dancing Robot, Subjective Judgement, Psycological Engineering Design, Semantic Defferencial Technique

\section{1. 緒产}

ダンス・ロボットは, パフォーマンス・ロボットの 1 つの形態であり, 音楽に合わせたダンスというパフォー マンスにより，人々に安らぎや楽しい感覚を与える事を 目的とし，産業用ロボットと対照的な種々の概念を持つ. すなわち, 産業用ロボットでは, その評価を生産性や効 率に求めることができるのに対し，ダンス・ロボットで は, スタイルや動作パターンに対する好感度が, 重要な 評価因子となる.

以上の事を踏まえてダンス・ロボットを製作した. コ ンセプトを「柔らかさ」「親しみやすさ」「可愛らしさ」 においてスタイリング設計を行ない,「滑らか」で「優し い」動作のために, 形状記憶合金アクチュェータを手足 の駆動に用い, バレーの型を実現した. また, ロボット 全体は, 任意方向に舞台上を移動できる.

原稿受付 1990 年 6 月 15 日

* 早稲田大学理工学部

** エイム研究所
産業ロボットが，効率などで評価されるように，製作 したパフォーマンス・ロボットに最終的に評価と反省を 与え，以降の設計製作の量にしなければならない。しか し，上に述べた様に，パフォマンス・ロボットの評価 因子は, 完全に観賞者の主観に委小られており, 観賞者 個人個人の趣味の差も大きく，産業用ロボットに較べて 一般的な評価が困難となる. そこで, 本論文では, 心理 学で利用されている主観的評価法の1つである SD 法 (semantic differrential technique)をマイコン上で実現 し,パフォーマンス・ロボットの評価を試みた.

\section{2. 開発諸元と方法}

\section{1 スタイリング設計}

パフォーーンス・ロボットの第 1 目的は, 観賞者に安 らぎや楽しい感覚を与えることであるので, スタイリン グ設計が重要である. 本ロボットは, イメージをアンデ ルセン童話の「鉛の兵隊」に登場するバレリーナに求め た. ロボットの外形設計に当たっては, 曲面設計法・モ アレ計測法"などの手法にて，そのイメージ・スケッチ， 


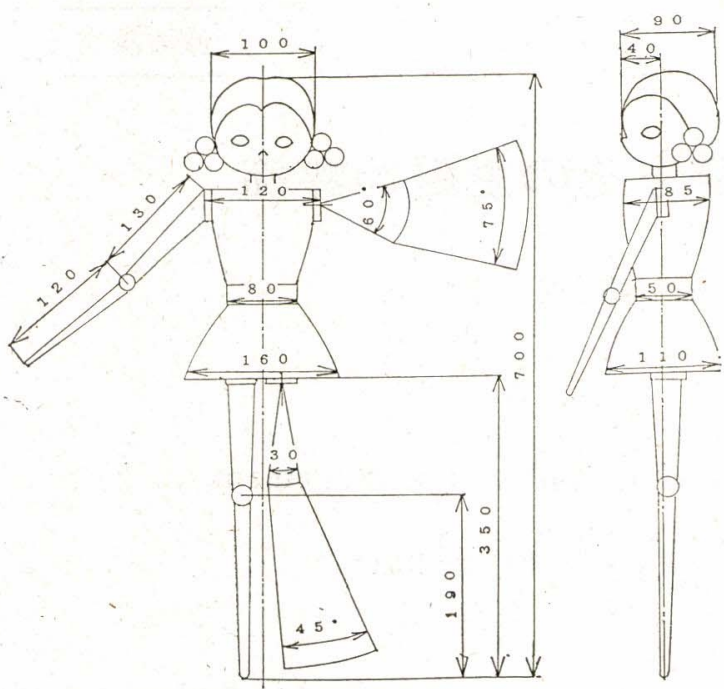

Fig. 1 Design of Performance Robot イメージ・モデルを作製した。

\section{2 実機の諸元}

イメージ・モデルをベースに, 実機のハードウェア設 計を行なった. 外観図をFig. 1, 外観写真を Fig. 2 に示 †.

このロボットの肩関節・时関節・膝関節には, それそ゚ れ $\phi 0.25[\mathrm{~mm}]$ の細線による形状記憶合金アクチュエ 一タが取り付けられ，パルス通電することにより手足が 可動する. また, 全体の移動は, $X Y$ 軸方向に置かれた

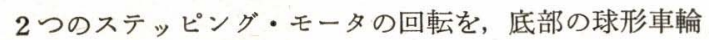
に伝えることにより行なっている. $X Y$ 軸 2 つのステッ ピング・モータの回転数及び回転比を制御することによ り，縦横斜めの任意方向に移動できる.

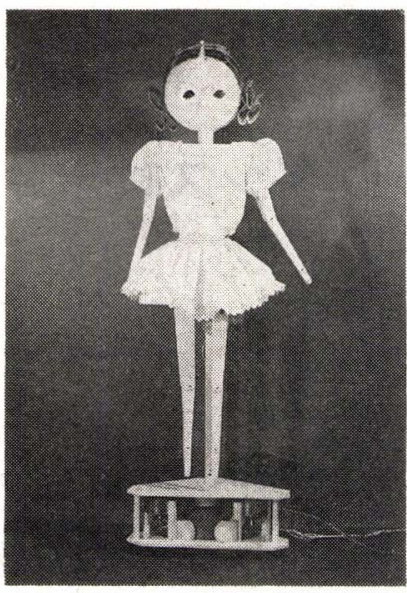

Fig. 2 The appearance of dancing robot (F)

以上の動作は, 8 ビットマイコンにて制御される. ブ ロック図を Fig. 3 に示す. 動作パターンは, プログラム としてROM に格納されており, 手足の動作と全体の移 動を同期させた演技を行なら、な狺, ロボットはワンポ ード・マイコンを搭載した自立型動作が基本であるが, 通信ケーブルを用いた外部ュンピュータからのマニュア ル操作型動作も可能である.

本体及び手足には，エポキシあるいはアクリル樹脂を 使用して，軽量化を図っている.

\section{3 性能結果}

このロボットは, 形状記憶合金アクチュエータにて駆 動され, 肩関節垂直方向 60 [deg], 肘関節 120 [deg], 滕関節 90 [deg] の屈曲と伸展ができた. その結果, ク ラシック・バレイの基本動作をとることが出来た. 動作 例を Fig. 4 に示す. 音楽に合わせて連続的にダンスを

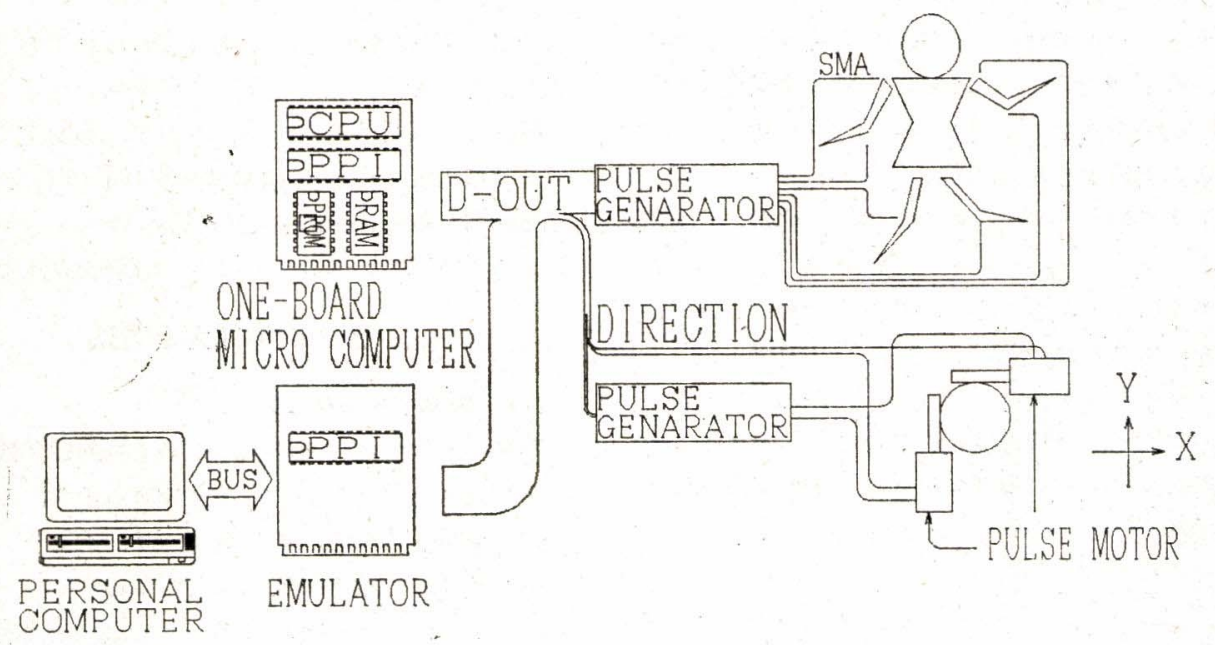

Fig. 3 System diagram 


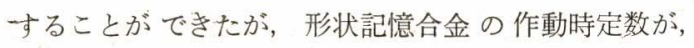
40.01 [ sec] 程度であるので, 激しい動作に対する追従性 塱劣っていた。 ロボットを取り付けている台車は, 平均 $30[\mathrm{~mm} / \mathrm{sec}]$ で移動する.

\section{SD 法による主観的評価}

心理学の分野では, 以前からオスグッドの開発した $\mathrm{SD}$ 法による心理測定が行なわれている22. 最近では, こ .の方法は物理系や工学系分野にも利用され, 主観的評価 として定着しつつある゙'. 前述したように, パフォーマ ンス・ロボットは, 観賞者に「やさしい」等の感情を抱 かせることができたかにより，その評価が行なわれるが， それは，個々人の主観的評価である. そこで, SD 法に よる評価を試みた。

まず,このダンス・ロボットの写真を, Fig. 5 に示す 他のパフォーマンス・ロボットの写真と一緒に被検者に 提示し, 印象を答光ても5 万。具体的には, Table 1 に 示したアンケート用紙上の 15 の形容詞対のそれぞれに 関して, どちらの形容詞に印象が近いかを数直線上にマ ークしてもらら方法である.

今回は，大学生男女 10 人ずつの被検者を得た。 その
アンケートを元に，分析を行なった. アンケート採取以 降の諸作業は, 16 ビットパーソナルコンピュータによ り行なった. その手順を Fig. 6 に示す. 形容詞対の相関 係数の計算結果を Table 2 に示す. 次に因子析出の計算 を行なら。因子析出とは,

$$
\begin{aligned}
R & =A_{1} A_{1}{ }^{t}+A_{2} A_{2}{ }^{t}+A_{3} A_{3}{ }^{t}+\cdots \\
\dot{R}: & \text { 相関係数マトリックス }
\end{aligned}
$$

Table 1 couples of adjectives in this questionnaire

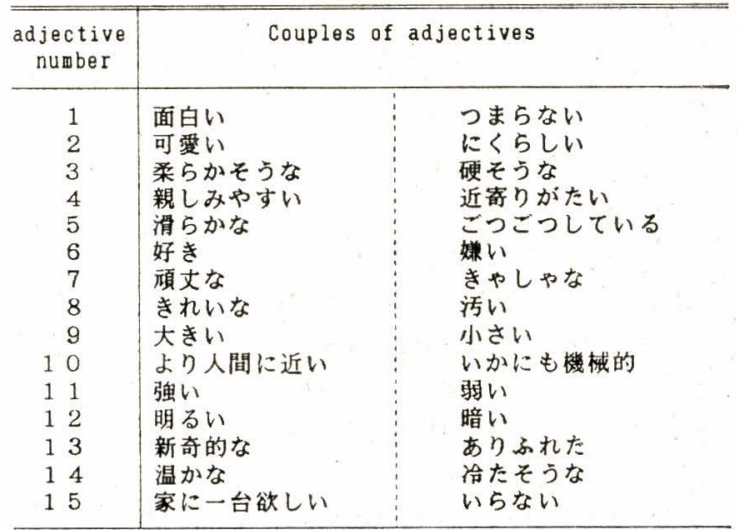
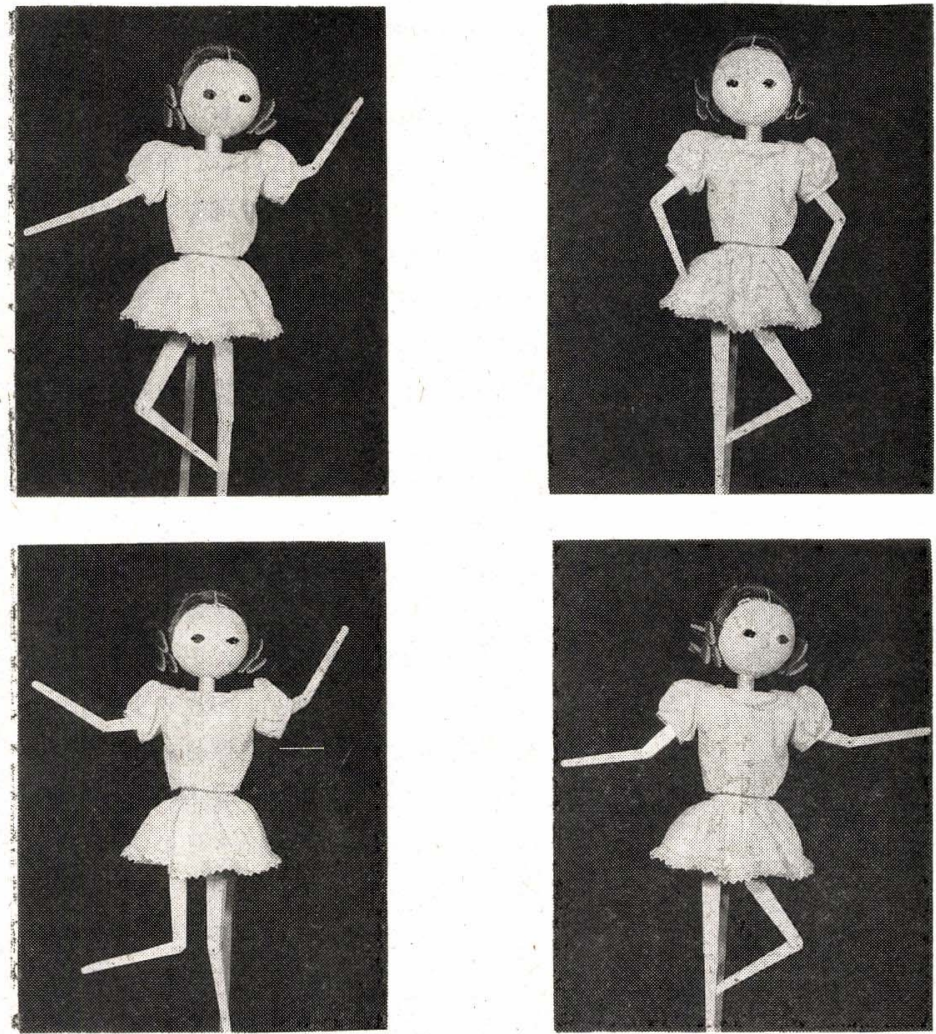

日本ロポット学会誌 9 巻 2 号

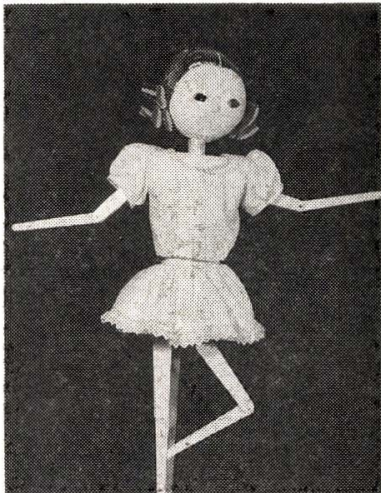

Fig. 4 Action of dancing robot
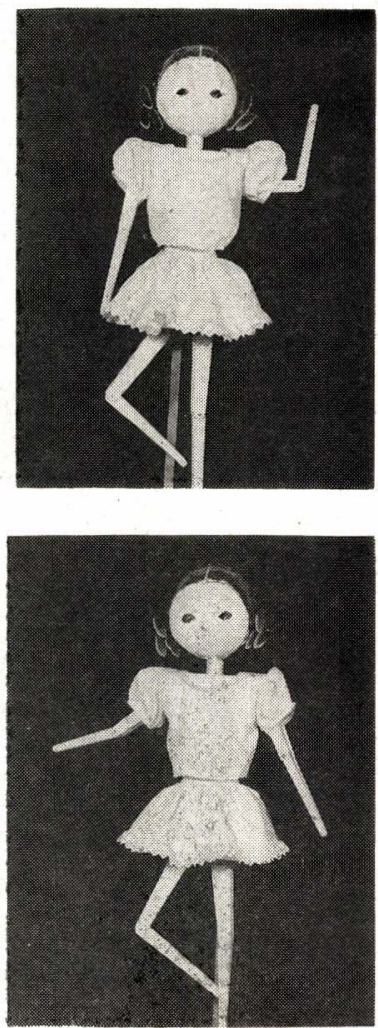

1991 年 4 月 
Table 2 coefficient of correlation

\begin{tabular}{|c|c|c|c|c|c|c|c|c|c|c|c|c|c|c|c|}
\hline $\begin{array}{l}\text { adjective } \\
\text { number }\end{array}$ & 1 & 2 & 3 & 4 & 5 & 6 & 7 & 8 & 9 & 10 & 11 & 12 & 13 & 14 & 15 \\
\hline 1 & 100 & 27 & -03 & 22 & 32 & 41 & -16 & 23 & -18 & 02 & -07 & 25 & 15 & -03 & 06 \\
\hline 2 & & 100 & 16 & 05 & 37 & 42 & 24 & -09 & 24 & -22 & 00 & 00 & 36 & 12 & 11 \\
\hline 3 & & & 100 & 40 & 16 & 18 & 41 & 10 & -22 & 45 & 01 & -18 & -12 & 21 & 12 \\
\hline 4 & & & & 100 & 36 & 28 & 09 & 28 & -28 & 32 & 26 & -06 & -05 & 21 & 40 \\
\hline 5 & & & & & 100 & 56 & 13 & 05 & 13 & 15 & 14 & 31 & 18 & .29 & 41 \\
\hline 6 & & & & & & 100 & 28 & 06 & -06 & 12 & 12 & 34 & 12 & 27 & 20 \\
\hline 7 & & & & & & & 100 & -07 & -10 & 18 & 36 & 11 & -11 & 18 & -01 \\
\hline 8 & & & & & & & & 100 & -37 & 03 & 08 & 23 & 25 & -12 & 31 \\
\hline 9 & & & & & & & & & 100 & -30 & 04 & -21 & 34 & 30 & 00 \\
\hline 10 & & & & & & & & & & 100 & -05 & 25 & -15 & 31 & 17 \\
\hline 11 & & & & & & & & & & & 100 & 04 & 21 & 20 & 32 \\
\hline 12 & & & & & & & & & & & & 100 & 28 & 20 & 23 \\
\hline 13 & & & & & & & & & & & & & 100 & 46 & 50 \\
\hline 14 & & & & & & & & & & & & & & 100 & 52 \\
\hline 15 & & & & & & & & & & & & & & & 100 \\
\hline
\end{tabular}

$A_{\imath}:$ 第 $i$ 因子列ベクトル

のように，行列をべクトルの積と和に分解することであ

る. 因子析出計算結果を Table 3 に示す.この場合は, 3 次で近似できた。すなわち，それぞれの形容詞対は， 表を横に見て，第 1 因子, 第 2 因子, 第 3 因子）といら

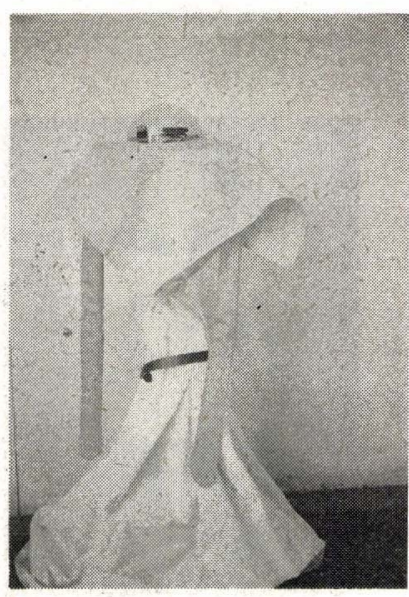

$\mathrm{P}$

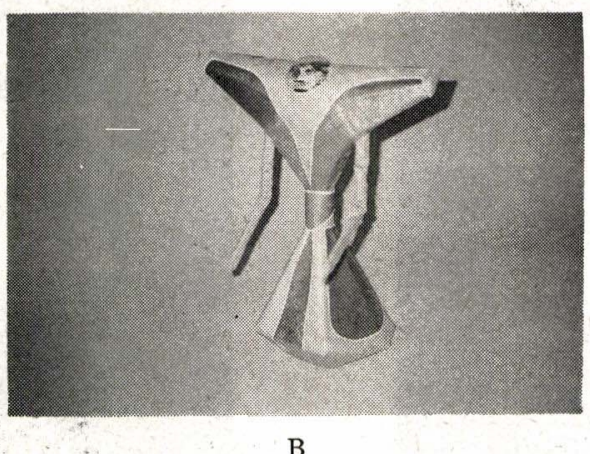

Fig. 5 Performance Robots
座標を得ることが判る、形容詞の位置をグラフィックス で表現した例を Fig. 7 に示す. 画面を見ながら, 表示面 の選択・座標軸の回転・座標軸への距離の和を最小にす る回転角度の計算などが行える，以上の操作により，似 かよった形容詞対を集めてグループとし，また互いに直 交関係にある形容詞対グループを捜し出す。 この例では, Fig.7 の図中で曲線に囲まれ たように，3つの形容詞対グループが見つ かった.これらの方向に延びる直交軸を持 つ空間を意味空間と呼び, ロボットは,こ れらの視点から人々から捉えられているこ とが分かる、またこれらの形容詞対グル ープに属さない他の形容詞対は, 分析に有 益でないとして無視する。

次に，実際に分解できた主因子に対して， 特徵を人々にアピールできる名称をつける。 すなわち，これが意味空間の座標軸名とな る.この作業だけは, プログラムが介在で きず，分析者の腕で，分かりやすくなった り分かりにくくなったりする工程である.

次に, ロボット毎の意味空間上の位置を 計算する，あるロボットに対して，アンケ 一トの平均值を座標軸毎にそれぞれ計算し て，それをそのロボットの意味空間上の座 標とする，今回つけた座標軸名と，各々の ロボットの意味空間上の座標を, Table 4 に示し，それを 3 次元グラフィックスで表 現した例を, Fig. 8 に示す.

この分析システムの性能を早さから評価 してみる. 項目別の実行時間を, Table 5 に示す. アンケート入力後は, 合計で平均 30 [sec] 程度しかからず, 何もせずに計 
算結果を待つだけの時間は, 最高で 10 [sec]なので, イライラさせられることもなかった. いろいろなアンケ 一トに対して，いろいろなグループ分けするなどの分析 を多数行なっても苦にならないであろら.

Table 3 factor loading

\begin{tabular}{|c|c|c|c|}
\hline \multirow{2}{*}{$\begin{array}{l}\text { adjective } \\
\text { number }\end{array}$} & \multicolumn{3}{|c|}{ factor loading } \\
\hline & lst factor & 2nd factor & 3rd factor \\
\hline $\begin{array}{ll} & 1 \\
& 2 \\
& 3 \\
& 4 \\
& 5 \\
& 6 \\
& 7 \\
& 8 \\
& \\
& 9 \\
1 & 0 \\
1 & 1 \\
1 & 2 \\
1 & 3 \\
1 & 4 \\
1 & 5\end{array}$ & $\begin{array}{r}0.358 \\
0.319 \\
0.410 \\
0.553 \\
0.617 \\
0.641 \\
0.340 \\
0.338 \\
-0.166 \\
0.377 \\
0.313 \\
0.414 \\
0.356 \\
0.487 \\
0.618\end{array}$ & $\begin{array}{r}0.223 \\
0.396 \\
-0.477 \\
-0.346 \\
0.306 \\
0.222 \\
-0.282 \\
-0.164 \\
0.541 \\
-0.342 \\
-0.089 \\
0.220 \\
0.541 \\
0.251 \\
0.128\end{array}$ & $\begin{array}{r}0.156 \\
0.516 \\
0.284 \\
0.093 \\
0.282 \\
0.375 \\
0.176 \\
-0.278 \\
0.085 \\
-0.098 \\
-0.087 \\
-0.334 \\
-0.380 \\
-0.180 \\
-0.403\end{array}$ \\
\hline Weight & 15.955 & 11.462 & 9.144 \\
\hline$\%$ & 43.6 & 31.3 & 25.0 \\
\hline
\end{tabular}

また，この分析システムは，操作が対話型であり，ま た, Fig. 7 やFig. 8 に示すように,グラフィックス表示

Table 4 factor score

\begin{tabular}{|c|c|c|c|c|c|c|c|}
\hline \multicolumn{2}{|c|}{ factor } & \multicolumn{2}{|c|}{ olevents } & \multicolumn{4}{|c|}{ values of robots } \\
\hline No. & nase & No. & adjectives & B & $\mathbf{P}$ & $\mathbf{K}$ & $\mathbf{F}$ \\
\hline 1 & $\begin{array}{l}\infty< \\
\text { छn }\end{array}$ & $\begin{array}{ll}12 & 2 \\
14\end{array}$ & $\begin{array}{l}\text { 明るい } \\
\text { 温かな }\end{array}$ & -0.025 & 0.475 & 0.050 & -0.025 \\
\hline 2 & やさ & $\begin{array}{l}3 \\
4\end{array}$ & $\begin{array}{l}\text { 来らかそうな } \\
\text { 舶しみやすい }\end{array}$ & -0.250 & 0.650 & 0.475 & -0.375 \\
\hline 3 & $\begin{array}{l}\text { 目を } \\
\text { 引く }\end{array}$ & $\begin{array}{l}1 \\
5 \\
6\end{array}$ & $\begin{array}{l}\text { 面白い } \\
\text { 骬らかな } \\
\text { 好点 }\end{array}$ & 0.283 & 0.317 & 1.117 & 0.717 \\
\hline
\end{tabular}

Table 5 run period of programs and input

\begin{tabular}{l|c|c}
\hline type of works & circuastance & $\begin{array}{c}\text { run period } \\
\text { Sec }\end{array}$ \\
\hline guestionnaire input & 20 men $\times 4$ concepts & 180 \\
\hline $\begin{array}{l}\text { calculating coeffi- } \\
\text { cient of correlation }\end{array}$ & & 10 \\
\hline $\begin{array}{l}\text { calculating } \\
\text { factor loading }\end{array}$ & 15 couples of \\
adjectives & 7 \\
\hline $\begin{array}{l}\text { rotation axis } \\
\text { (average) }\end{array}$ \\
\hline 3D graphic & 4 concepts & 1 \\
\hline
\end{tabular}

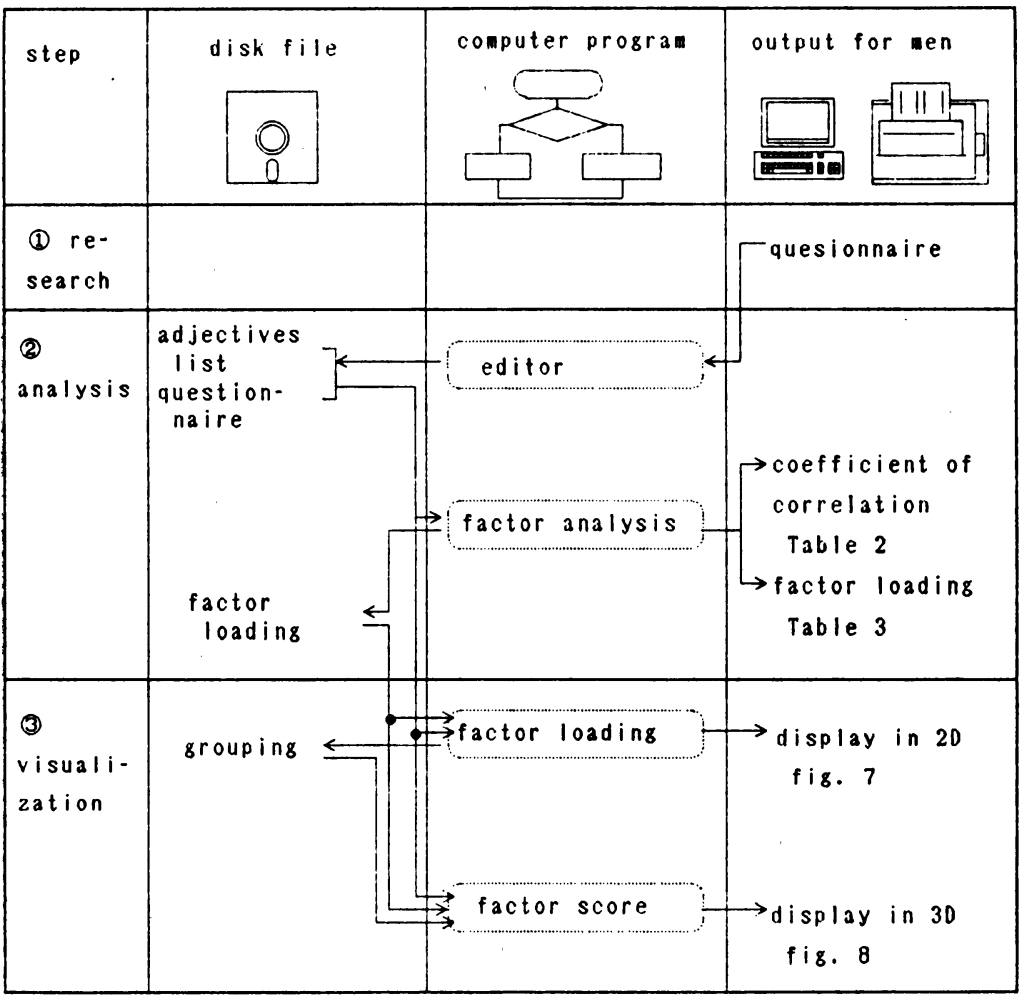

Fig. 6 Process of Semantic Defferencial Technique with personal computer 
8

(Q)

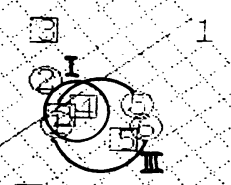

1

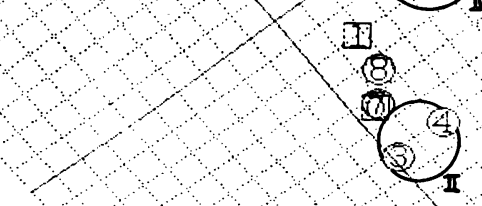

ゆ面白心

○可愛い

(滑的伀

6 好声

究明引い

目新奇的存

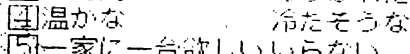

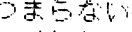

E<らし

ごつごつしている.

搛以

暗!

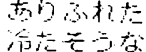

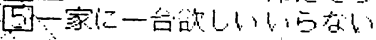

\section{团強以}

定上り人間に近， い加も機械的

(9)大きい

(8)奇蹢な

(頑丈な

小さい

活以

(4)親しみりすい

(3)柔らか子うな

きゃしゃ龙

近奇りがたい

硬そうな

2まら等い

E<EL

こ๐ごつしてい

㐮以

污以

小施

3

II

(a)

(1)
II 4

(5)

0

(8)

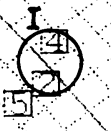

一ら滑らかな

2

(8) 奇哑药

Q大きい

②万人間に近い

प1工強 :

いかも機械的

53 :

\section{5一家に一台欲しいいらない \\ 「匈温かな 㸮芯もうな

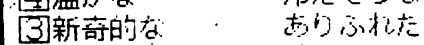 \\ ○頑丈な \\ 暗以 \\ II[象親しみやすいるう

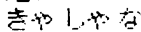 \\ 近奇りがたい。 \\ 硬方な}

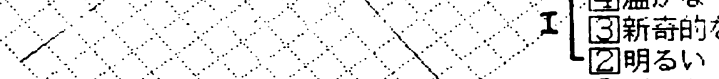

Fig. 7 Display of adjectives' positions

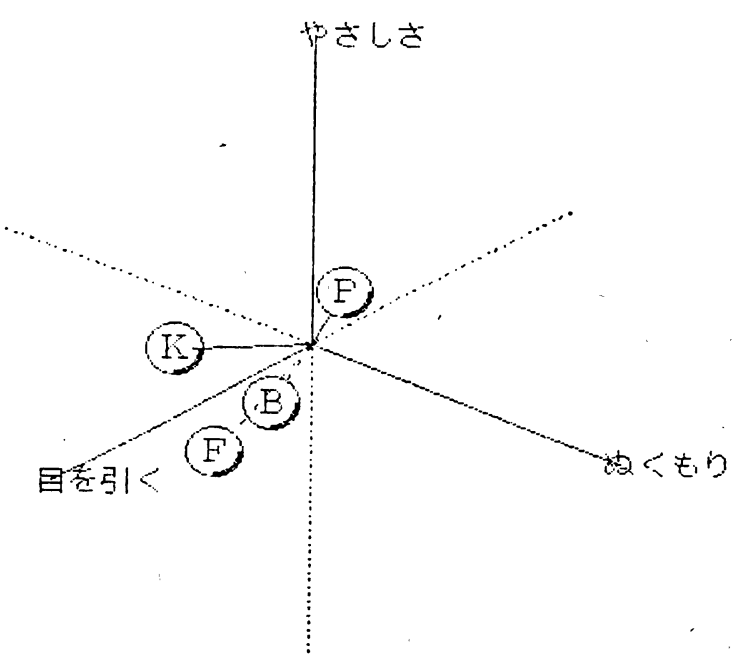

$\mathrm{E}$ 青
$\mathrm{P}$ 条村
$\mathrm{E}$ 藤城

Fig. $83 \mathrm{D}$ display of each robot's position in Image Space 
による表現が基本であるので, 分析結果を数值からでな く，見た目で捉えることができる.すなわち，全体の作 業は，SD 法の原理を知らなくてもかまわず，操作がす ぐに憶えられ，数字に苦手な人でも，因子評価が行える わけである.

\section{4. 結果に対する考察}

ダンスをするロボットといら開発目的であるために, 企画段階から「柔らかさ」「親しみやすさ」「可愛らし さ」を感じるよらにスタイリング・デザインした。 また， 静かで滑らかな動作を行なわせるために形状合金アクチ ニエータを使用し，脚も屈伸できる機能を付した．その 結果, バレーの基本姿勢がとれ，動きは滑らかであった. しかし，形状記憶合金アクチュエータ使用による応答限 界があり，すばやい動作はできなかった，しかし，形状 記憶合金の加熱方法を改良すれば， $0.01[\mathrm{sec}]$ までの応 答は, 可能となるはずである. また, 全体移動用の機構 も，ステッピング・モータのパワーアップや伝達部の改 善により, 移動速度の向上が期待できる. これは, 今後 の課題である.

以上のハード機能評価と同時に, 観賞者の主観的評価 が重要である．SD 法の利用を試みた結果,「温もり」 「やさしさ」「目を引く」といら 3 つ評価軸で, パフォ ーマンス・ロボットが評価されていると想像できた. ま た, 15 の形容詞対の内, 「一家に一台欲しい」「新奇的 な」「より人間に近い」等の形容詞は, 類似範疇の形容詞 対が見つけられず, 直交性もなく，評価それ自体に何ら 貢献しないことが判った. あまりに複雑な表現で，人に より形容詞の解釈自体が大きく異なってしまったためと 思われる. 今後のアンケートでは, 新しい形容詞対と差 し替えるなどの方策が必要である. しかしながら換言す れば，SD 法を行ならことにより，適切な評価のため, 形容詞を淘汰できた訳であり，自己改良が可能である. このように，今後の評価に応用できることも， SD 法の 特徴である.ソフトウェアの操作性や速度などについて は, 専門家でなくても使用でき, グラフィック表示によ り, 判定がわかりやすく，かつ容易に行えるといら簡便 性が得られた.

パフォーンス・ロボットに対する主観分析結果であ るが, Fig. 8 から判るように, 検体 $\mathrm{K} か ゙$ 特に好意的な評
価を得られたようである.ダンス・ロボットFは，目を 引くという因子で高得点だったが，狙いとした「温め り」「やさしさ」では, 他に比して少々難があるようであ る. 兩因子で得点の高かった P の結果を参考にすると, 柔らかな布地を使うといらのは, 得点を稼ぐいい方法と 思われる. また，「やさしさ」の点で，BF と PK が好対 照をなしている．Kがメタリック調であるのにも関わら ず,「やさしい」評価を得ている点から考えて, 裙広がり な外形が「やさしさ」を演出しているのではないかと思 われる.

今後ダンス・ロボットの開発において, スケッチの段 階で，また演技動作時に SD 法を用い, 改良の一助とし たい.

\section{5. ま め め}

(1) ダンス・ロボットを開発した.このロボットは, バレーの手足の基本形をとることができる.

(2)このロボットは, 観賞用となるので,「やわらか さ」「親しみやすさ」「可愛らしさ」のイメージを持つこ とを目標として，デザインをした.

(3) 形状記憶合金アクチュエータを用いて, 動作を静 かに, 滑らかにした.

(4) SD 法で, このロボットの印象の主観的評価を行 なった．また，前報パフォーマンス・ロボットの SD 評価結果と比較し, 検討した.

(5) SD 法の対話型因子分析グラフィック表示ソフト を開発した。

なお, 本研究は, 東京電力(株)開発研究所からの委託 研究であることを付記して，ここに感謝の辞を呈するも のである.

\section{参考文 献}

1）設計美学：日経メカニカル（1987）10/30 日号

2）岩下豊彦：SD法によるイメージの測定, 川島書店(1987)

3）長町三生 : 自動車と感性工学, 自動車研究 11 刊 1 号 (1989), 2-6

4) 井口信洋, 内田 純, 木村裕美, 濱島幸生 : パフォーマ ソス・ロボットの開発, 日本ロボット学会誌第 6 巻 5 号 pp. 33-41, 1988

5）Z80 の使い方，オーム社 (1983)

6） マイコン知能ロボットの招待, 月刊 ASCII (1985) 3 月号 